part in its circulation as salt dues in that of the ocean. In conclusion, I would say, look at the isolherms between $65^{\circ} 42^{\prime} \mathrm{S}$, and $50^{\circ} \mathrm{I}^{\prime} \mathrm{S}$. published in Report No. 2 of the Challenger. May ro DigBY MurRay

\section{ANCIENT GLACIERS IN AUVERGNE}

FIAVING just returned from Auvergne, where I have been searching for the tracks of former glaciers among the old volcanoes of the Monts Dome and Mont Dore, I send a few notes to NATURE, in the hope that they may prove useful to other geologists who may explore that most remarkable and interesting country during the ensuing summer. My companions were three members of the Cotteswold Naturalist's Field Club, Sir W. V. Guise (the President), Sir David Wedderburn, and Mr. Lucy, all well versed in the phenomena presented by glaciation.

With regard to the Monts Dome and the country round Clermont Ferrand, it is evident that no glaciers have occupied the vales since the outpouring of the later lava currents, and the volcanic outbursts of the craters of the Puys de Dome; and yet, as I have already mentioned in the pages of NATURE, M. Le Coq discovered remains of the Mammoth, Tichorhine rhinoceros, and Spermophilus, which had been washed into drifts and fissures in the most. recent lava currents of Volvic and Gravenoire near Beaumont. Such drifts deserve especial attention, as they appear to owe their origin to a period when there was greater transportation of angular and subangular débris by rain-wash and melting snow, or neve, than there is at present. It may have been during this period that the northern animals became inhabitants of Central France. Such angular and sub-angular drifts may be seen in various localities as in the road which descends from the south side of Gergovia, between the village of Merdogne and the high road to Clermont Ferrand, and again at the base of the Puy Dallet, where the high road descends to the village of Dallet, and atmospheric drifts are seen to overlie the old river shingle of an ancient Allier. The geologist who examines the source of the old basaltic current which Mr. Scrope believes to have flowed from the Puy de Berzé, near St. Genest de Champantlle, and to have extended over the freshwater strata of Gergovia, may learn a good lesson as regards the deceitful appearances of glaciation often set up by granitic rocks. Most of the country between Ceyrat, near Mont Rognon, and Theix looks regularly "moutonéed," and may mislead anyone who has not become convinced, by careful examination, that this appearance is owing to atmospheric weathering, and the desquamation of the granitic rocks which separate at the joints and weather into rounded boulders assuming somerimes the aspect of blocs perchés. There are no signs of glaciation, however, among the older basalts which overlie the granite rocks, in so many localities, and which ought to show it if glaciation there bad been.

In the country of the Monts Dore the evidence is most puzzling, and in some respects contradictory. Arrived at Monts Dore des Bains we searched carefully for glacier evidences in the valley of the Dordogne and the gorges de l'Enfer and de la Cour, and though some of the knolls are rounded, and there is a vast amount of débris from the rocks around and above, nowhere could we see signs of true moraines, perched blocks, or the usual evidences of glacier action, and certainly the position of the masses of rock called "Les Trois Diables," which I believe are by some set down as blocs perchés, are far too close to the rocks in situ to allow us to attribute their transportation to a glacier rather than to a fall from the precipices above. They belong to the "Chemins du Diable," which are preparing for a similar descent. Again, and I must here state that I arrived at conclusions contrary to those of my friends, I believe that a glacier has descended, in long ago ages, down the valley of the Jordogne, but so long since that the vast masses of débris which have fallen from the rocks which skirt the valley, combined with the wear and tear of atmospheric agencies, the constant shifting of the bed of the Dordogne and its hundreds of tributary rills which during the meiting of the snows everywhere wash, roll, wear, and transport the débris of the vale, all have assisted in destroying and masking any glacier evidence there may have been in past times. I was led to this conclusion from the examination of the higher ground, and the detection of what $I$ believe to be moraine matter and transported rock masses, on the road between Mont Dore des Bains and Latour, as on the platform below the Rochers de Beauzac, \&c.

The Tranteine valley, where Dr. Hooker discovered the transported rock-masses and which he has already described in NATURF, lies at right angles to the Dordogne valley, runs due south, and faces the Cantal. It is difficult to understand why glacier relics should be preserved in this valley and none in that of the Dordogne. This difficulty, however, vanishes somewhat when surveying the difference in the contour of the ground, the difference in the watershed of streamlets, and the low hill against which the great rock-masses are stranded, consisting of moraine matter overlying beds of basaltic lava. The Tranteine valley may be reached by passing over the Col between the Pic de Sancy and Puy Ferrand, and turning down the gorge to the south, or by the long roundabout route through the village of Latour. We selected the former for our first attack, taking the Latour route two days later. I would here recommend as guide, Guillaume Pierre, of the Hotel Chabourg ainé, to whom I pointed out certain phenomena on descending the gorge, which I think are worthy of notice. I also recommend no one to attempt this route who is not a good walker- "Facilis descensus," \&c. The transported rocks, one of which Dr. Hooker sketched, lie stranded in moraine matter, which again rests on beds of black basalt, as may be seen at the little waterfall of the Tranteine stream. The rocks themselves come from the Pic de Sancy, and consist of what Scrope calls "porphyritic trachyte," but perhaps now they may be termed a granitic felstone or a felstone porphyry. Dr. Hooker calls them domite, but this term is now usually applied to the white, light, pulverulent rock like that of the Puy Sarcoui in the Puys de Dome. On the right and lefi of the transported rocks the hills are rounded, and blocs perchés are seen resting on them. There is a fine section on the Tranteine stream, en route to Picherande, where large transported rock-masses may be seen resting on glacial till. Following the valley down to the bridge which crosses the T'ranteine river between Latour and Picherande, the observer will find rounded surfaces and transported moraine matter, but a vast deal of atmospheric weathering has gone on since the days when the ice passed away.

Travelling down the valley of Besse to Lake Pavin, I thought I recognised glacier action; and again at the head of the valley of Chambon; but if glaciers ever flowed down these valleys, it is evident that they must have done so before the exuption of the Puy de Tartaret or the Puy d'Eraignes. The occurrence of the volcanic cone of Tartaret right in the middle of the valley of Chambon is fatal to the supposition that a glacier of any size ever came down from the mountains since the outburst of the cinders and lavas of Tartaret.

If, therefore, after three visits to the volcanic regions of Central France I may be permitted to give a broad view as to the time when glaciers swept down the valleys of Mont Dore, I should say that it was in days of old, when the Alpine glaciers reached the Jura, and the Rhine glacier swept over to the plains of Bavaria, when there were glaciers in the Vosges and in the Black Forest ; and that when those ice rivers melted and passed away, so also did the glaciers of Mont Dore.

W. S. SYMONDS

P $\in$ ndock Rectory, Tewkesbury, June 5 